\title{
PENGEMBANGAN PERANGKAT PEMBELAJARAN IPA BERBASIS INKUIRI TERBIMBING TERHADAP PENCAPAIAN HASIL BELAJAR SISWA SEKOLAH DASAR
}

\author{
Amri Amal*, Fajri Basam \\ Program Studi Pendidikan Guru Sekolah Dasar, Fakultas Keguruan dan Ilmu Pendidikan, \\ Universitas Muhammadiyah Makassar, Indonesia \\ *Korespondensi. E-mail: amriamal@unismuh.ac.id
}

\begin{abstract}
Abstrak
Penelitian ini bertujuan untuk mengetahui: (1) Menghasilkan perangkat pembelajaran IPA berbasis inkuiri terbimbing yang berkualitas di Sekolah Dasar; (2) mengetahui hasil belajar peserta didik setelah digunakan perangkat pembelajaran inkuiri terbimbing yang telah dikembangkan. Penelitian dan pengembangan ini meliputi 4 tahap yaitu: (1) tahap pendefinisian; (2) tahap perancangan; (3) tahap pengembangan; dan (4) tahap penyebaran. Instrumen penelitian ini meliputi: 1) penilaian ahli dan guru terhadap perangkat pembelajaran IPA berbasis inkuiri terbimbing yang dikembangkan; 2) soal tes, kemudian dianalisis dengan analisis data uji validasi dan tes hasil belajar. Hasil penelitian adalah; (1) Perangkat pembelajaran IPA berorientasi inkuiri terbimbing yang meliputi: a) Rencana Pelaksanan Pembelajaran (RPP), b) Lembar Kerja Siswa (LKS), dan Tes hasil belajar, menunjukkan bahwa perangkat pembelajaran ini memenuhi kriteria sangat valid, praktis, dan efektif digunakan; (2) Pengembangan perangkat pembelajaran berorientasi inkuiri terbimbing efektif digunakan dalam pembelajaran IPA. Indikator efektif dalam penelitian ini dilihat dari peningkatan hasil belajar pretest-posttest dan selisih hasil pretest-posttest.
\end{abstract}

Kata Kunci: Pengembangan Perangkat Pembelajaran; Inkuiri Terbimbing; Pembelajaran IPA SD; dan Hasil Belajar.

\section{DEVELOPMENT OF SCIENCE LEARNING DEVICES BASED ON GUIDED INQUIRY ON ACHIEVEMENTS OF BASIC SCHOOL STUDENT LEARNING OUTCOMES}

\begin{abstract}
This study aims to determine: (1) Producing quality guided inquiry-based science learning devices in elementary schools, (2) knowing the learning outcomes of students after using the guided inquiry learning tool that has been developed. This research and development covers 4 stages, namely: (1) defining stage; (2) the design stage; (3) development stage; and (4) the deployment stage. This research instrument includes: 1) expert and teacher assessment of the developed inquiry inquiry-based science learning device; 2) test questions, then analyzed by analyzing validation test data and learning outcomes test. The results of the study are; (1) Guided inquiry-oriented science learning devices which include: a) Learning Implementation Plans (RPP), b) Student Worksheets (LKS), and Learning Outcomes Tests, indicating that this learning tool meets very valid, practical, and effective criteria for use; (2) The development of guided inquiry-oriented learning tools is effectively used in science learning. Effective indicators in this study are seen from the increase in pretest-posttest learning outcomes and the difference in pretest-posttest results.
\end{abstract}

Keywords: Development of Learning Devices; Guided Inquiry; Learning Natural Sciences at Elementary School; Learning Outcomes.

Copyright $@ 2018$, JRPD, ISSN 2615 - 1723 (Print), ISSN 2615 - 1766 (Online) 


\section{PENDAHULUAN}

Pembelajaran IPA merupakan bidang ilmu yang mempelajari tentang alam yang berorientasi tidak hanya pada produk atau hasil tapi juga menekankan pada proses bagaimana suatu konsep bisa terbentuk, sehingga dalam mempelajari IPA, siswa akan berhubungan dengan cara mencari tahu tentang alam secara sistematis. Mempelajari IPA bukan hanya penguasaan kumpulan pengetahuan yang berupa fakta-fakta, konsepkonsep, atau prinsip-prinsip saja tetapi juga merupakan suatu proses penemuan. Pembelajaran IPA merupakan pembelajaran yang terdiri dari produk, proses, dan sikap sebagai acuan atau batasan untuk mengetahui sejauh mana kompetensi siswa dalam pembelajaran IPA, setiap guru menentukan suatu standar nilai. Hal ini dimaksudkan agar guru mengetahui sejauh mana siswa dalam memahami pembelajaran.

Kegiatan pembelajaran yang dilakukan di sekolah seharusnya dibuat menyenangkan agar siswa dapat belajar dengan baik sehingga didapatkan hasil pembelajaran yang optimal. Kemampuan guru dalam melaksanakan pembelajaran merupakan salah satu faktor yang dapat mempengaruhi keberhasilan belajar siswa. Pembelajaran yang melibatkan siswa, akan membuat siswa lebih memahami materi pembelajaran yang disampaikan oleh guru sehingga pengalaman belajar yang diterapkan kepada siswa harus bersifat student centered.

Model POE (Predict-Observe-Explain) merupakan model pembelajaran yang membelajarkan siswa dengan membuat prediksi atas suatu kejadian berdasarkan konsepsi mereka sendiri, kemudian mengobservasi kejadian tersebut secara nyata, dan yang terakhir menjelaskan hasil pengamatan mereka serta menjelaskan ketidaksesuaian prediksi mereka dengan keadaan yang sebenarnya.
Penyebab rendahnya hasil belajar IPA di Sekolah Dasar adalah model, pendekatan, strategi dan metode pembelajaran yang kurang bervariasi sehingga aktivitas peserta didik dalam proses pembelajaran masih minim. Metode mengajar yang sering dilakukan adalah ceramah, mencatat, dan mengerjakan soal. Proses pembelajaran hanya berlangsung satu arah dimana guru menjelaskan materi dan rumus, memberi contoh soal, serta memberikan pekerjaan rumah (PR), sehingga peserta didik dalam proses pembelajaran menjadi penerima informasi passif. Hal inilah yang membuat peserta didik kurang aktif belajar IPA, sehingga hasil belajar yang diperoleh peserta didik tidak maksimal. Disamping itu kemampuan setiap peserta didik yang bervariasi dalam memahami suatu pelajaran juga berpengaruh pada pencapaian hasil belajar IPA, ada yang memiliki kemampuan pemahaman yang cepat dan ada juga yang lambat.

Meskipun telah menerapkan pendekatan saintifik dalam proses pembelajaran namun belum memperlihatkan adanya peningkatan pada hasil belajar IPA yang diperoleh, karena metode pengajaran yang dipilih belum tepat dan masih menempatkan guru sebagai sumber belajar (teacher centered) disamping itu hanya sesuai untuk mengembangkan ranah pengetahuan tapi tidak untuk proses dan sikap yang diperlukan untuk berpikir kritis. Akibatnya kebanyakan peserta didik memiliki pengetahuan kognitif yang cukup baik tetapi mereka kurang mampu menerapkan pengetahuan keterampilan maupun sikap dalam kehidupan nyata. Oleh karena itu, seorang guru dituntut agar dapat memahami dan memiliki keterampilan yang memadai dalam menerapkankan berbagai model pembelajaran.

Berdasarkan beberapa pertimbangan, maka penulis tertarik untuk memilih salah satu model pembelajaran yang dapat diterapkan di kelas karena mengingat: 1) Masih rendahnya

Copyright (C2018, JRPD, ISSN 2615 - 1723 (Print), ISSN 2615 - 1766 (Online) 


\section{Jurnal Riset Pendidikan Dasar, 01 ( 2), Oktober 2018 (116-123)}

Amri Amal, Fajri Basam

daya serap peserta didik, dalam hal ini hasil belajar peserta didik masih rendah; 2) Berdasarkan hasil observasi diperoleh bahwa keterlibatan belajar peserta didik selama proses pembelajaran di kelas masih rendah, yaituc. sekitar $36 \%$ peserta didik yang aktif dalam proses pembelajaran, sedangkan peserta didik yang lainnya asyik dengan kegiatannya sendiri; 3) Peserta didik mengalami kesulitan dalam mengingat dan memahami pelajaran IPA, peserta didik dapat menyatakan konsep tetapi tidak dapat memaknainya; 4) Kurangnya peningkatan kualitas pembelajaran IPA sehingga guru dituntut kreatif dalam menyajikan berbagai strategi, metode dand. model pembelajaran yang sesuai.

$$
\text { Dalam pelaksanaan model }
$$
pembelajaran inkuiri di kelas, terdapat beberapa prinsi-prinsip yang perlu menjadi perhatian bagi seorang guru. Dengan memperhatikan prinsip-prinsip tersebut, pembelajaran yang menggunakan model pembelajaran inkuiri diharapkan dapat berjalan secara maksimal sesuai dengan apa yang telah direncanakan. Menurut Hartono (2014: 65), ada beberapa prinsip-prinsip utama yang harus diperhatikan oleh setiap guru dalam penggunaan model pembelajaran inkuiri, yaitu:

a. Berorientasi pada pengembangan intelektual

Tujuan utama dari model pembelajaran inkuiri adalah pengembangan kemampuan berfikir. Dengan demikian model pembelajaran inkuiri ini, selain berorientasi pada hasil belajar, juga berorientasi pada proses belajar. Karena itu, kriteria keberhasilan dari proses pembelajaran dengan menggunakan model pembelajaran inkuiri bukan ditentukan dari sejauh mana peserta didik dapat menguasai materi pelajaran, melainkan sejauh mana peserta didik beraktivitas mencari dan menemukan suatu makna melalui proses berpikir.

\section{b. Prinsip bertanya}

Peran guru yang harus dilakukan dalam menggunakan model pembelajaran inkuiri adalah sebagai penanya. Sebab, kemampuan peserta didik dalam menjawab setiap pertanyaan termasuk bagian dari proses berfikir.

\section{Prinsip interaksi}

Proses pembelajaran adalah proses interaksi, baik interaksi antara guru dengan peserta didik, guru dengan lingkungan, dan peserta didik dengan lingkungan. Pembelajaran sebagai proses interaksi menempatkan guru sebagai pengatur lingkungan yang mengarahkan peserta didik dapat mengembangkan kemampuan berpikirnya.

Prinsip belajar untuk berpikir

Belajar bukan hanya mengingat sejumlah fakta, melainkan juga proses berpikir (learning how to think), yaitu proses mengembangkan potensi seluruh otak, baik otak kiri maupun otak kanan, kecerdasan, emosi, spritual dan intelektual. Menurut Asrori (2009: 221) mengatakan bahwa berdasarkan kemampuan yang dimiliki oleh otak dalam menyerap, mengelola, dan menyampaikan informasi, maka cara belajar individu dapat dikelompokkan ke dalam tiga gaya belajar: 1) gaya belajar visual, 2) gaya belajar auditif, dan 3) gaya belajar kinestetik.

e. Prinsip keterbukaan

Prinsip yang bermakna adalah pembelajaran yang menyediakan berbagai kemungkinan sebagai hipotesis yang harus dibuktikan kebenarannya. Dalam hal ini, tugas guru adalah menyediakan ruang untuk memberikan kesempatan kepada peserta didik dalam mengembangkan hipotesis, dan secara terbuka membuktikan kebenaran hipotesis yang diajukan.

Selama proses inkuiri berlangsung, seorang guru dapat mengajukan suatu pertanyaan atau mendorong peserta didik untuk mengajukan pertanyaan-pertanyaan mereka sendiri. Pertanyaannya bersifat openended, memberi kesempatan kepada peserts didik untuk menyelidiki sendiri dan mereka mencari jawaban sendiri (tetapi tidak hanya satu jawaban yang benar). Menurut Trianto Copyright (C2018, JRPD, ISSN 2615 - 1723 (Print), ISSN 2615 - 1766 (Online) 
(2013: 168), kemampuan yang diperlukan untuk melaksanakan pembelajaran inkuiri adalah sebagai berikut:

a. Mengajukan pertanyaan atau
permasalahan
Kegiatan inkuiri dimulai ketika pertanyaan atau permasalahan diajukan. Untuk meyakinkan bahwa pertanyaan sudah jelas, pertanyaan tersebut dituliskan di papan tulis, kemudian peserta didik diminta untuk merumuskan hipotesis.

b. Merumuskan hipotesis

Hipotesis adalah jawaban sementara atas pertanyaan atau solusi permasalahan yang dapat diuji dengan data. Untuk memudahkan proses ini, guru menanyakan kepada peserta didik gagasan mengenai hipotesis yang mungkin. Dari semua gagasan yang ada, dipilih salah satu hipotesis yang relevan dengan permasalahan yang diberikan.

c. Mengumpulkan data

Hipotesis digunakan untuk menuntun proses pengumpulan data. Data yang dihasilkan dapat berupa tabel, matriks, atau grafik.

\section{d. Analisis data}

Peserta didik bertanggung jawab menguji hipotesis yang telah dirumuskan dengan menganalisis data yang diperoleh. Faktor penting dalam menguji hipotesis adalah pemikiran 'benar' atau 'salah'. Setelah memperoleh kesimpulan dari data percobaan, peserta didik dapat menguji hipotesis yang telah dirumuskan. Bila ternyata hipotesis itu salah atau ditolak, peserta didik dapat menjelaskan sesuai dengan proses inkuiri yang telah dilakukannya.

e. Membuat kesimpulan

Langkah penutup dari pembelajaran inkuiri adalah membuat kesimpulan sementara berdasarkan data yang diperoleh peserta didik.

\section{METODE}

Penelitian ini termasuk ke dalam jenis penelitian pengembangan (research and development) yang bertujuan untuk menghasilkan perangkat pembelajaran yang valid, praktis, dan efektif sehingga layak digunakan di sekolah dasar. Dengan menggunakan model pembelajaran inkuiri terbimbing maka kevalidan, kepraktisan, dan keefektifan perangkat pembelajaran yang di kembangkan dapat diuraikan sebagai berikut.

Populasi penelitian ini adalah siswa SDN NO. 41 Malewang Kabupaten Takalar semester ganjil tahun ajaran 2016/2017. Pada penelitian ini, peneliti menggunakan kelas $\mathrm{V}$ sebagai kelas eksperimen. Desain uji coba menggunakan pretest-postest with control group design (Samsudi, 2009). Analisis data yang digunakan meliputi uji prasyarat analisis dan uji keefektifan produk.

\section{HASIL DAN PEMBAHASAN}

Hasil penelitian uji coba yang telah dilakukan selanjutnya digunakan untuk melihat sejauh mana kualitas perangkat pembelajaran yang telah dikembangkan memenuhi kriteria valid, praktis, dan efektif. Selain itu dilihat pula sejauh mana pencapaian hasil belajar dengan menggunakan pembelajaran berbasis inkuiri terbimbing.

Berdasarkan analisis hasil validasi perangkat pembelajaran maka dapat disimpulkan bahwa perangkat pembelajaran model inkuiri terbimbing yang terdiri dari Rencana Pelaksanaan Pembelajaran (RPP), Lembar Kerja Siswa (LKS), dan Tes Hasil Belajar menurut penilaian ahli telah memenuhi kriteria kevalidan, dengan kategori sangat valid. Hasil validasi perangkat pembelajaran ini dapat di lihat pada Gambar 1 . 


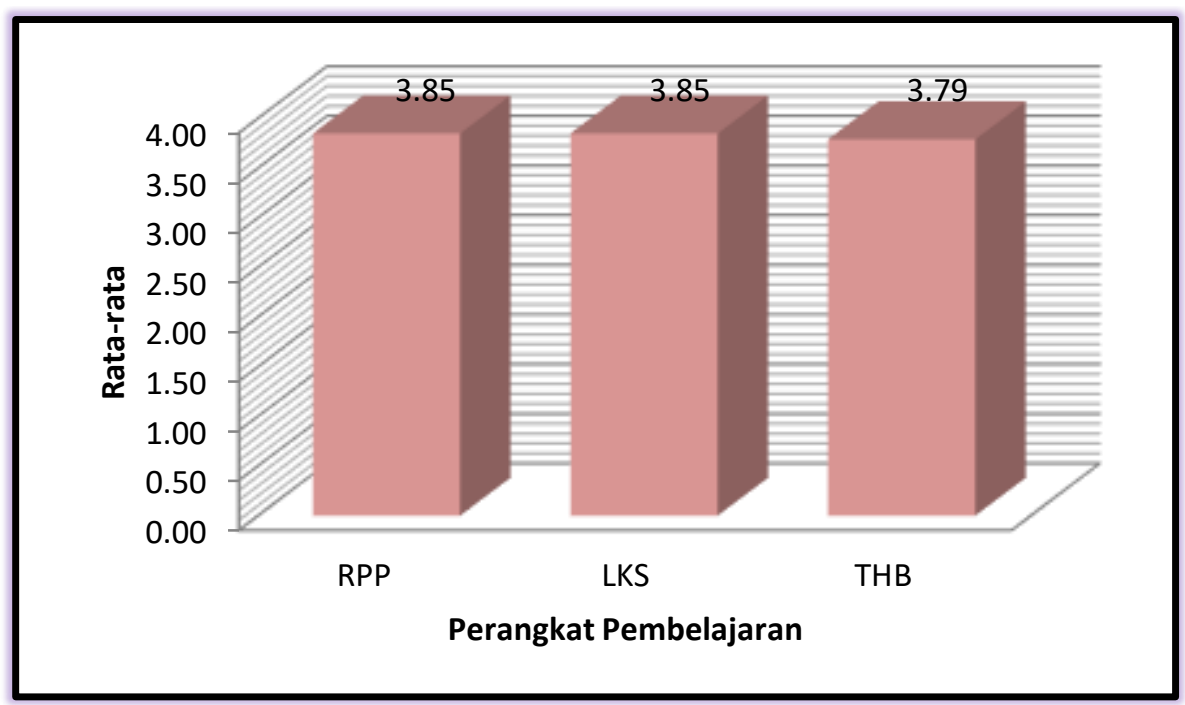

Gambar 1 Validasi Perangkat Pembelajaran berorientasi Inkuiri Terbimbing

Analisis deskriptif bertujuan untuk mengetahui sejauh mana tingkat perkembangan hasil belajar siswa sebelum dan setelah mengikuti proses pembelajaran yang terdiri atas empat kali pertemuan. Data diolah menggunakan program Microsoft Office Excel 2007, untuk melihat hasil belajar siswa sebelum dan setelah menggunakan perangkat Model inkuiri terbimbing. Dari perhitungan analisis deskriptif diperoleh hasil pada Tabel 1.

Tabel 1. Hasil Belajar Kelas Eksperimen

\begin{tabular}{ccc} 
Skor & \multicolumn{2}{c}{ Eksperimen } \\
& Pretest & Posttest \\
\hline Jumlah Siswa & 28 & 28 \\
Nilai Minimum & 40 & 52 \\
Nilai Maksimum & 84 & 92 \\
Mean & 68,00 & 82,00 \\
Standar Deviasi & 10,92 & 8,96 \\
\hline
\end{tabular}

Hasil belajar siswa kelas uji coba dengan jumlah 28 siswa untuk pretest nilai minimum 40; nilai maksimum 84 ; mean 68,00 , dan standar deviasi 10,92 dan untuk posttest nilai minimum 52; nilai maksimum 92 ; mean 82,00 , dan standar deviasi 8,96. Jadi dilihat dari perbadingan pretest dan posttest mengalami peningkatan. Lebih jelasnya dapat dilihat pada histogram

Gambar

2.

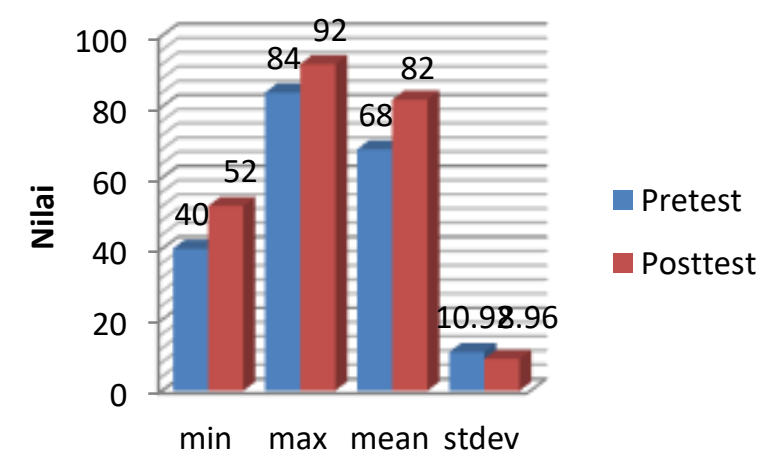

Gambar 2. Perbandingan Pretest dan Posttest

Pembahasan kevalidan, kepraktisan, dan keefektifan perangkat pembelajaran dalam penelitian ini, dibahas satu persatu berdasarkan pertimbangan hasil uji coba yang telah dilakukan.

\section{Kevalidan perangkat pembelajaran}

Hasil penilaian dari dua validator, menunjukkan keseluruhan komponen perangkat pembelajaran dan instrumen penelitian dinyatakan sangat valid.

Hasil analisis kevalidan untuk perangkat pembelajaran yang meliputi (1) Rencana Pelaksanaan Pembelajaran (RPP) diperoleh skor rata-rata 3,85 yang berarti sangat valid; (2) Lembar Kerja Siswa (LKS)

Copyright $(2018$, JRPD, ISSN 2615 - 1723 (Print), ISSN 2615 - 1766 (Online) 
diperoleh skor rata-rata 3,85 yang berarti sangat valid; (3) Tes Hasil Belajar diperoleh skor rata-rata 3,79 yang berarti sangat valid. Kesimpulan dari kedua validator rata-rata menyatakan bahwa perangkat pembelajaran yang dikembangkan dapat digunakan dengan tanpa revisi.

\section{Kepraktisan perangkat pembelajaran}

Kepraktisan perangkat pembelajaran dapat dilihat dari tingkat keterlaksanaan RPP yang digunakan saat pembelajaran berlangsung. Nilai kepraktisan perangkat pembelajaran diambil dari hasil observasi dua orang pengamat yang telah ditunjuk untuk menilai sejauh mana perangkat RPP tersebut dapat dilaksanakan.

Dari hasil pengamatan keterlaksanaan RPP berada pada nilai rata-rata 1,75 dengan kategori terlaksana seluruhnya. Hal ini berarti bahwa perangkat RPP yang telah dikembangkan dapat secara praktis digunakan dalam pembelajaran berbasis inkuiri terbimbing khususnya untuk magnet. Sehingga dapat dikatakan bahwa dari segi kepraktisannya, perangkat yang telah dikembangkan dapat digunakan dalam pembelajaran pada materi magnet dengan menggunakan model pembelajaran berbasis inkuiri terbimbing. Perangkat pembelajaran yang dikembangkan ini dapat mengantar peserta didik untuk menemukan sendiri pengetahuannya untuk memahami sesuatu sehingga peserta didik diharapkan dapat mengkonstruksi sendiri pengetahuannya.

Selama berlangsungnya pembelajaran dengan model pembelajaran berbasis inkuiri terbimbing untuk materi magnet, telah dilakukan pengamatan terhadap aktivitas peserta didik dalam mengikuti proses pembelajaran. Beberapa kegiatan yang menjadi perhatian dalam aktivitas ini adalah (1) orientasi; (2) merumuskan masalah; (3) Merumuskan hipotesis; (4) mengumpulkan data; (5) analisis data; (6) merumuskan kesimpulan.

Hasil pengamatan selama pelaksanaan uji coba menunjukkan bahwa keseluruhan aktivitas peserta didik yang diamati berada dalam interval waktu ideal. Artinya, aktivitas peserta didik dalam pembelajaran dengan menggunakan model pembelajaran berbasis inkuiri terbimbing ideal.

Keidealan aktivitas yang dilakukan oleh peserta didik tidak terlepas dari efektifnya perangkat yang telah dirancang sebelumnya untuk mengendalikan waktu yang dipergunakan untuk pelaksanaan pembalajaran dengan menggunakan model pembelajaran berbasis inkuiri terbimbing. Rencana Pelaksanaan Pembelajaran (RPP) dengan setiap fase kegiatannya mampu dilaksanakan dengan baik sehingga pelaksanaan pembelajaran melalui model pembelajaran berbasis inkuiri terbimbing dapat terlaksana dengan baik. Demikian halnya dengan LKS, tugas/soal-soal yang disajikan dalam LKS dianggap bisa diselesaikan dalam waktu yang telah ditetapkan dengan mempertimbangkan aktivitas interaksi antara peserta didik dengan guru, dan peserta didik dengan peserta didik lainnya. Dengan demikian rata-rata waktu yang dipergunakan peserta didik beraktivitas dalam mengerjakan tugas untuk kegiatan pembelajaran dengan menggunakan model pembelajaran berbasis inkuiri terbimbing sangat baik.

\section{Keefektifan perangkat pembelajaran}

Untuk melihat ketercapaian kompetensi dasar dan indikator terhadap pembelajaran melalui model pembelajaran berbasis inkuiri terbimbing, maka dilakukan tes hasil belajar. Hasil belajar siswa kelas uji coba dengan jumlah 28 siswa untuk pretest nilai minimum 40; nilai maksimum 84 ; mean 68,00 , dan standar deviasi 10,92 dan untuk posttest nilai minimum 52; nilai maksimum 92; mean 82,00 , dan standar deviasi 8,96. Jadi dilihat dari perbadingan pretest dan posttest mengalami peningkatan.

Brickman (2009) menyatakan bahwa kegiatan pembelajaran inkuiri terbimbing dapat mengembangkan kemampuan scientific proces sehingga mahasiswa dapat membangun pengetahuannya secara mandiri. Senada Copyright (2018, JRPD, ISSN 2615 - 1723 (Print), ISSN 2615 - 1766 (Online) 


\section{Jurnal Riset Pendidikan Dasar, 01 ( 2), Oktober 2018 (116-123)}

Amri Amal, Fajri Basam

dengan Brickman (2009), Ashiq Hussain, dkk. (2011) menyimpulkan bahwa model pembelajaran inkuiri terbimbing dapat meningkatkan hasil belajar siswa dan kemampuan mengaplikasikan konsep-konsep IPA dalam permasalahan nyata.

Dari pelaksanaan uji coba ini dapat dijelaskan bahwa model inkuiri terbimbing yang dikembangkan ini berdasarkan tahapantahapannya, mampu memberikan motivasi dan minat yang besar, suasana belajar yang menyenangkan bagi peserta didik, selanjutnya peserta didik membangun konsep dari apa yang dilakukan dan yang ditemukannya yang pada akhirnya dapat memberikan hasil belajar sesuai tujuan yang diharapkan. Hal ini menjadi seiring dengan pendapat Wina Sanjaya (2008:126) bahwa penyusunan langkah-langkah pembelajaran, pemanfaatan berbagai fasilitas dan sumber belajar semuanya diarahkan dalam upaya pencapaian tujuan.

Dengan memperhatikan prosedur dan langkah-langkah pengembangan Rencana Pelaksanan Pembelajaran (RPP) berbasis inkuiri terbimbing serta pemilihan model maupun metode pembelajaran yang sesuai maka hasil belajar peserta didik dapat meningkat dari hasil yang diperoleh dalam penelitian ini. Kecenderungan guru untuk memanfaatkan fasilitas laboratorium demi terlaksananya metode eksperimen atau demonstrasi, bukan hal yang dapat membatasi kreativitas guru untuk menemukan metode yang tepat dan bersesuaian dengan lingkungan belajar peserta didik. Dengan memperhatikan kondisi lingkungan belajar serta karakteristik peserta didik yang bersesuain dengan model yang dipilih maka hasil belajar dapat lebih optimal.

\section{SIMPULAN}

Berdasarkan hasil penelitian yang dilakukan tentang pengembangan model pembelajaran Predict, Observe, Discuss, dan Explain (PODE) untuk mata pelajaran IPA di SDN Kompleks IKIP Makassar, maka dapat disimpulkan: (1) Perangkat pembelajaran berorientasi Inkuiri Terbimbing yang meliputi: a) Rencana Pelaksanan Pembelajaran (RPP), b) Lembar Kerja Peserta Didik (LKPD), dan c) Tes hasil belajar, menunjukkan bahwa perangkat pembelajaran ini memenuhi kriteria sangat valid, praktis, dan efektif digunakan. (2) Perangkat pembelajaran berorientasi inkuiri terbimbing efektif digunakan dalam pembelajaran IPA kelas V SDN No. 41 Malewang Kabupaten Takalar tahun ajaran $2016 / 2017$. Indikator efektif dalam penelitian ini dilihat dari peningkatan hasil pretest-posttest

Saran yang dapat diberikan: (1) guru IPA diharapkan dapat menerapkan model inkuiri terbimbing untuk pokok bahasan yang lain; (2) perlu dilakukan uji coba lebih luas terhadap produk model yang dihasilkan dalam pembelajaran IPA di sekolah dasar; (3) Guru dalam menggunakan perangkat ini dapat memperhatikan langkah-langkah atau kegiatan pembelajaran serta aspek-aspek yang mempengaruhi kualitas pembelajaran sehingga memudahkan peserta didik dalam proses pembelajaran.

\section{DAFTAR PUSTAKA}

Asrori, M. 2009. Psikologi Pembelajaran. Bandung: CV. Wacana Prima.

Aqib, Z. 2014. Model-model, Media, dan Strategi Pembelajaran Kontekstual (INOVATIF). Bandung: Yrama Widya.

Brickman, P., "Effects of Inquiry-Based Learning on Students' Science Literacy Skills and Confidence", International Journal for The Scholarship of Teaching and Learning. Vol. 3 (2), 2009.

Borg, W. R. \& Gall, M. D. 1983. Educational Research. Fourth edition. NewYork: Longman Inc.

Dimyati \& Mudjiono. 2009. Belajar dan Pembelajaran. Jakarta: PT. Rineka Cipta

Depertemen Pendidikan Nasional. 2008. Pengembangan Lember Kerja Siswa. 
Jakarta: Depertemen Pendidikan Nasional.

Hartono, Rudi. 2014. Ragam Model Mengajar yang Mudah Diterima Murid. Jogjakarta: DIVA Press.

Hussain, A., 2011. "Physics Teaching Methods: Scientific Inquiry vs Traditional Lecture", International Journal of Humanities and Social Learning. Vol. 1 (19).

Kunandar. 2013. Penilaian Autentik. Jakarta: PT RajaGrafindo Persada.

Kemendiknas. 2007. Permendiknas Nomor 41 Tahun 2007 tentang Standar Proses Pendidikan Dasar dan Menengah. Jakarta.

Nurhadi. 2004. Pembelajaran Kontekstual. Malang: Univessitas Negeri Malang

Purwanto. 2013. Evaluasi Hasil Belajar. Yogyakarta: Pustaka Pelajar.

Putra, S., R. 2013. Desain Belajar Mengajar Kreatif Berbasis Sains. Jogjakarta: DIVA Press.

Rusman. 2012. Belajar dan Pembelajaran Berbasis Komputer. Bandung: ALFABETA.

Sanjaya, Wina. 2008. Strategi Pembelajaran Berorientasi Standar Proses Pendidikan. Jakarta: Kencana Prenada Media Group.

Samsudi. 2009. Disain Penelitian Pendidikan. Semarang: Unnes Press.

Trianto. 2011. Model Pembelajaran Terpadu. Jakarta: Bumi Aksara.

Trianto. 2013. Mendesain Model Pembelajaran Inovatif-Progresif. Surabaya: Kencana Prenada Media Group. 